\title{
Relation between immunocytological features of bronchoalveolar lavage fluid and clinical indices in
} sarcoidosis

\author{
GILLIAN M AINSLIE, LW POULTER, ROLAND M DU BOIS \\ From the Departments of Immunology and Thoracic Medicine, Royal Free Hospital, London
}

ABSTRACT This study was designed to determine whether cell populations in bronchoalveolar lavage fluid represent a reflection of disease activity in sarcoidosis. Bronchoalveolar lavage fluid cells were obtained from 22 patients with sarcoidosis and from 10 normal control subjects and investigated by immunocytological methods. A panel of monoclonal antibodies was used to determine the relative proportions of phenotypically distinct subsets of macrophages and lymphocytes in the patients with sarcoidosis and to correlate them with clinical indices, such as disease duration, serum angiotensin converting enzyme, the chest radiograph, and results of pulmonary function tests. Patients with sarcoidosis had a higher percentage than the normal subjects of macrophage like cells expressing RFD1 (a class II associated antigen preferentially expressed by dendritic cells), an epithelioid cell antigen (RFD9), and a circulating monocyte antigen (UCHMI). The increase in RFD1 ${ }^{+}$cells appeared to be due to detection of antigen by this antibody on cells that were also expressing phenotypic markers of classical tissue macrophages (RFD7). The lymphocytes in lavage fluid from patients with sarcoidosis were characterised by increased expression of activation markers, such as interleukin-2 receptors (anti-Tac $\left.{ }^{+}\right)$, HLA-DR $\left(\right.$RFDR $\left.^{+}\right)$, and "blast" forms (expressing above normal concentrations of CD7 antigen). This was associated with increased proportions of the CD4 ${ }^{+}$ (helper-inducer) $\mathrm{T}$ cell subset. Patients with sarcoidosis whose clinical indices suggested activity showed an increased number of macrophages coexpressing RFD1 and RFD7 antigens, of macrophages expressing UCHM1 and lymphocytes expressing activation markers. The expression of these markers was also increased on lavage cells from patients with radiographic evidence of widespread disease (chest radiographic stage II and III), but there was no relation with disease duration, pulmonary function, or serum angiotensin converting enzyme activity. Immunocytological analysis of lavage cells offers a probe for studying the pathogenesis of sarcoidosis and may be of value in monitoring disease activity.

\section{Introduction}

\begin{abstract}
Alveolar macrophages and lymphocytes have an important role in the immune mechanisms underlying sarcoidosis. ${ }^{12}$ Previous studies have shown that alveolar macrophages are extremely heterogeneous and no clear difference has been seen between patients with different types of interstitial lung disease and normal control subjects in the proportions of cells staining positively with different monoclonal antibodies. ${ }^{3-5}$

The aim of our study was to use a panel of

Address for reprint requests: Dr G M Ainslie, Department of Respiratory Medicine, University of Cape Town Medical School, Observatory 7925, Cape Town, South Africa.

Accepted 21 February 1989
\end{abstract}

monoclonal antibodies to try to correlate cell membrane markers with disease activity and other clinical indices in sarcoidosis. Several studies have attempted to identify indices that correlate with disease activity and could be used to predict or monitor its course. Inconclusive data have accumulated from studies looking at differential cell counts, ${ }^{6-11}$ or lymphocyte subsets in bronchoalveolar lavage fluid, ${ }^{11} 12$ gallium scans, ${ }^{6-1012}$ and serum angiotensin converting enzyme activity ${ }^{671012-14}$ The initial promise that a "high intensity alveolitis," 15 defined as more than $28 \% \mathrm{~T}$ lymphocytes in the lavage fluid differential count plus a high gallium score, predicted disease activity and clinical deterioration has been tempered by conflicting results from other series. ${ }^{671617}$ Recently Turner-Warwick et al have suggested that a high quality chest radiograph together with pulmonary function tests 
were as good as any of the more sophisticated, expensive, and invasive tests in monitoring disease progression. ${ }^{19}$ The clinical value of bronchoalveolar lavage, or at least of the differential cell count, which is the test most commonly used with lavage fluid, has yet to be proved. ${ }^{20}$

Immunocytological analysis of macrophages and lymphocytes in bronchoalveolar lavage fluid might provide a useful tool to investigate the pathogenetic mechanisms concerned in the initiation and progression of sarcoidosis, and could be of clinical value in monitoring disease activity.

\section{Methods}

\section{STUDY POPULATIONS}

\section{Control subjects}

We studied seven normal volunteers (six male, one female; age 22-41 years) and three patients (one female, two male; age 32-70 years) who were having fibreoptic bronchoscopy for investigation of a single episode of haemoptysis (chest radiograph normal) or a localised mass lesion (bronchoalveolar lavage performed on the normal lung). Three (one volunteer, two patients) were current cigarette smokers; none was receiving medication.

\section{Patients with sarcoidosis}

The patients with sarcoidosis consisted of 11 women and 11 men (age 26-76 years) with histological evidence of non-caseating granulomas in transbronchial lung biopsy specimens, in the appropriate clinical setting and in the absence of other known causes of pulmonary granulomatous disease. Eight patients were ex-smokers (five having stopped more than a year before lavage), and three smoked less than five cigarettes a day. Disease duration varied from three months to 12 years (mean 2.3 years). One patient had a stage 0 chest radiograph (that is, normal), five had stage I (clear lung fields but bilateral hilar lymphadenopathy), 11 had stage II (bilateral hilar lymphadenopathy and lung field shadowing), and five had stage III (lung field shadowing but no hilar adenopathy). Only one of these five had had enlarged hilar nodes noted previously. Eleven $(50 \%)$ had a forced vital capacity (FVC) or transfer factor for carbon monoxide (TLCO), or both, less than $80 \%$ of predicted normal values. Fourteen had abnormally raised serum angiotensin converting enzyme activity. Seven patients had evidence of extrathoracic disease (peripheral lymphadenopathy in three, hepatomegaly, myopathy and peripheral lymphadenopathy in one, and hepatomegaly and nasal and skin lesions in one each). No patient was receiving treatment at the time of lavage; eleven subsequently started taking corticosteroids because of symptoms, deteriorating pul- pulmonary function, or persistent or increasing shadowing on the chest radiograph. This was instituted by the doctor who was looking after the patient, who had no knowledge of our assessment of disease activity or immunocytology. Table 1 shows clinical details of the patients at the time of bronchoalveolar lavage.

\section{CLINICAL SCORE}

We used the scoring system shown in table 2 to assess $\overrightarrow{0}$ clinical activity in each patient at the time of bronchoalveolar lavage, and again at follow up 6-12 $\vec{\sigma}$ months later. This gives a maximum score of 10 points; arbitrarily, any patient with a score of 5 or more was $x$ judged to have active disease. Similar systems have $\vec{f}$ been used in other studies. ${ }^{1422} 23$ The maximum mark os for radiographic abnormality was $3 / 10$ and for pul- $O$ monary function tests $4 / 10$, so that neither could $\vec{\circ}$ influence the total score unduly. The International Labour Office (ILO) chest radiograph scoring system $\vec{c}$ was used in addition to staging so that the profusion of parenchymal shadowing could be measured in $\Phi$ patients with lung field shadowing. We found that $\overrightarrow{0}$ giving different weightings to the various components of the score failed to alter the total significantly.

On the basis of the initial score and the 6-12 months follow up 15 patients were judged to have active disease and seven inactive disease at the time of the bronchoalveolar lavage. None of the seven patients judged to have inactive disease developed active disease subsequently either as judged by score or in the opinion of the doctors looking after them. Of the 11 treated patients with active disease who received treatment, seven showed partial and four complete resolution. Of the four untreated patients who received no treatment two showed partial and two complete resolution. This suggests that a high score represents active disease rather than "burnt out" severe disease, in that the 15 patients judged to have active disease showed a substantial decrease in scores over the follow up period, with and without treatment (table 1).

\section{BRONCHOALVEOLAR LAVAGE}

Approval for the study was given by the hospital ethics committee and informed consent was obtained from all patients and volunteers.

Premedication was given one hour before the $\omega$ procedure and consisted of $10 \mathrm{mg}$ intramuscular papaveretum and $0.6 \mathrm{mg}$ atropine. The upper res- $\stackrel{\varrho}{\simeq}$

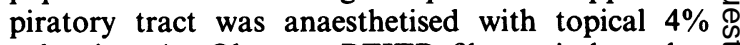
xylocaine. An Olympus BFITR fibreoptic bronchoscope was introduced transnasally into the lower $\frac{0}{0}$ respiratory tract, where $2 \%$ xylocaine was sprayed. $\underset{\mathbb{D}}{ }$ The instrument was then wedged in a lateral subseg- $\stackrel{\rho}{\Phi}$ mental bronchus in either the right middle or the right $\stackrel{\AA}{\circ}$ lower lobe of the supine patient. A total of $180-240 \mathrm{ml}$. of sterile $0.9 \%$ normal saline (corrected to $\mathrm{pH} 7.4$ with 
Table 1 Clinical details of patients with sarcoidosis

\begin{tabular}{|c|c|c|c|c|c|c|c|c|c|c|c|}
\hline \multirow[b]{2}{*}{$\begin{array}{l}\text { Patient } \\
\text { No }\end{array}$} & \multirow[b]{2}{*}{$\begin{array}{l}\text { Age } \\
(y)\end{array}$} & \multirow[b]{2}{*}{$\begin{array}{l}\text { Ethnic } \\
\text { group* }\end{array}$} & \multirow{2}{*}{$\begin{array}{l}\text { Disease } \\
\text { duration } \\
\text { (mo) }\end{array}$} & \multirow{2}{*}{$\begin{array}{l}\text { Extra- } \\
\text { thoracic } \\
\text { disease }\end{array}$} & \multirow{2}{*}{$\begin{array}{l}\text { Chest } \\
\text { radio- } \\
\text { graphst }\end{array}$} & & & & \multirow[b]{2}{*}{$\begin{array}{l}\text { Subsequent } \\
\text { treatment }\end{array}$} & \multicolumn{2}{|l|}{ Score $\ddagger$} \\
\hline & & & & & & \multicolumn{3}{|c|}{ (\% predicted) } & & At $B A L$ & $\begin{array}{l}\text { 6-12 mo } \\
\text { later }\end{array}$ \\
\hline $\begin{array}{l}1 \\
2 \\
3 \\
4 \\
5 \\
6 \\
7 \\
8\end{array}$ & $\begin{array}{l}28 \\
34 \\
31 \\
26 \\
30 \\
27 \\
39 \\
45\end{array}$ & $\begin{array}{l}\text { Asian } \\
\text { Black }\end{array}$ & $\begin{array}{r}72 \\
12 \\
6 \\
5 \\
3 \\
4 \\
24 \\
108\end{array}$ & $\begin{array}{l}\text { LN } \\
\text { LN, liver, } \\
\text { myopathy }\end{array}$ & $\begin{array}{l}\text { 0 } \\
\text { I } \\
\text { I } \\
\text { I } \\
\text { I } \\
\text { I } \\
\text { II } \\
\text { II }\end{array}$ & $\begin{array}{r}105 \\
80 \\
130 \\
105 \\
110 \\
110 \\
65 \\
95\end{array}$ & $\begin{array}{r}70 \\
100 \\
90 \\
105 \\
80 \\
115 \\
30 \\
80\end{array}$ & $\begin{array}{r}79 \\
32 \\
68 \\
32 \\
65 \\
40 \\
146 \\
98\end{array}$ & $\begin{array}{c}\bar{Z} \\
\bar{z} \\
\bar{z} \\
\text { Steroids } \\
-\end{array}$ & $\begin{array}{l}3 \\
2 \\
2 \\
2 \\
2 \\
2 \\
8 \\
5\end{array}$ & $\begin{array}{l}2 \\
1 \\
0 \\
0 \\
0 \\
0 \\
1 \\
0\end{array}$ \\
\hline $\begin{array}{l}9 \\
10 \\
11 \\
12 \\
13 \\
14 \\
15 \\
16 \\
17 \\
18 \\
19 \\
20 \\
21 \\
22\end{array}$ & $\begin{array}{l}33 \\
37 \\
56 \\
29 \\
35 \\
34 \\
32 \\
35 \\
30 \\
76 \\
60 \\
28 \\
26 \\
38\end{array}$ & $\begin{array}{l}\text { Asian } \\
\text { Asian } \\
\text { Black } \\
\text { Black }\end{array}$ & $\begin{array}{r}36 \\
72 \\
6 \\
6 \\
12 \\
46 \\
4 \\
6 \\
15 \\
6 \\
144 \\
18 \\
4 \\
6\end{array}$ & $\begin{array}{l}\text { Skin } \\
\text { Nose } \\
\text { Liver }\end{array}$ & $\begin{array}{l}\text { II } \\
\text { II } \\
\text { II } \\
\text { II } \\
\text { II } \\
\text { II } \\
\text { II } \\
\text { II } \\
\text { II } \\
\text { III } \\
\text { III } \\
\text { III } \\
\text { III } \\
\text { III }\end{array}$ & $\begin{array}{r}60 \\
110 \\
80 \\
65 \\
80 \\
100 \\
90 \\
60 \\
80 \\
60 \\
85 \\
90 \\
35 \\
110\end{array}$ & $\begin{array}{r}55 \\
120 \\
120 \\
70 \\
95 \\
70 \\
75 \\
75 \\
60 \\
80 \\
65 \\
90 \\
15 \\
80\end{array}$ & $\begin{array}{r}110 \\
43 \\
39 \\
52 \\
74 \\
72 \\
84 \\
52 \\
137 \\
69 \\
72 \\
101 \\
167 \\
35\end{array}$ & $\begin{array}{c}\text { Steroids } \\
\text { Steroids } \\
- \\
\text { Steroids } \\
\text { Steroids } \\
- \\
\text { Steroids } \\
\text { Steroids } \\
\text { Steroids } \\
\text { Steroids } \\
\text { Steroids } \\
\text { Steroids }\end{array}$ & $\begin{array}{l}9 \\
5 \\
5 \\
6 \\
6 \\
7 \\
6 \\
6 \\
7 \\
6 \\
6 \\
7 \\
7 \\
4\end{array}$ & $\begin{array}{l}4 \\
0 \\
0 \\
3 \\
2 \\
2 \\
2 \\
3 \\
2 \\
3 \\
3 \\
0 \\
1 \\
1\end{array}$ \\
\hline
\end{tabular}

*Other than caucasian.

†Classification: O-clear radiograph; I-bilateral hilar lymphadenopathy; II - bilateral hilar lymphadenopathy and lung field shadowing; III-lung field shadowing only.

LN-lymph node; FVC - forced vital capacity; TLCo-transfer factor for carbon monoxide; SACE-serum angiotensin converting enzyme activity in $\mathrm{nmol} / \mathrm{ml} / \mathrm{min}$ (normal range $15-53$ ); BAL - bronchoalveolar lavage.

†See under "Methods."

$8.4 \%$ sodium bicarbonate and maintained at $37^{\circ} \mathrm{C}$ ) was introduced in $60 \mathrm{ml}$ aliquots and removed by gentle suction. The fluid was colleced into a sterile siliconised glass bottle at $4^{\circ} \mathrm{C}$.

\section{PROCESSING THE LAVAGE FLUID}

The total cell count was determined from an aliquot of neat unfiltered lavage fluid in a modified Neubauer haemocytometer. Viability of the cells was assessed in all cases by trypan blue exclusion and was always greater than $70 \%$. Mucus strands were removed by filtering the fluid through a layer of sterile gauze. The fluid was then centrifuged at $450 \mathrm{~g}$ for 10 minutes and the supernatant was decanted from the cell pellet. The cells were then washed twice with Hanks's balanced

Table 2 Clinical scoring system

\begin{tabular}{lllll}
\hline & \multicolumn{3}{l}{ Empirical weighting } & \\
\cline { 2 - 5 } & 0 & 1 & 2 & 3 \\
\hline Symptoms & Absent & Present & & \\
Signs & Absent & Present & & \\
Chest radiograph & 0 & BHL & ILO1 & ILO2-3 \\
FVC (\% predicted) & $>80 \%$ & $70-80 \%$ & $<70 \%$ & \\
TLCO (\% predicted) & $>80 \%$ & $70-80 \%$ & $<70 \%$ & \\
SACE & Normal & Raised & & \\
\hline
\end{tabular}

BHL-bilateral hilar lymphadenopathy; ILO-International Labour Organisation classification of interstitial lung shadowing. ${ }^{21}$ For other abbreviations see table 1 . salt solution (HBSS) and the cell suspension was adjusted to a concentration of $2-3 \times 10^{5}$ cells $/ \mathrm{ml}$. Cytospin slide preparations were obtained with 50 $100 \mu \mathrm{l}$ aliquots in a Shandon Cytospin II (Shandon Instruments, Runcorn). The cytospin slides were then air dried for one to two hours and fixed in a 1:1 chloroform:acetone mixture for 10 minutes. They were air dried again for one to two hours and stored (wrapped in plastic cling film) at $-20^{\circ} \mathrm{C}$ until use (from one week to 2 years). Differential counts were performed immediately on cytospin preparations stained with May-Giemsa-Grünwald, a total of 300 600 cells being counted.

\section{IMMUNOCYTOLOGICAL ANALYSIS}

The panel of monoclonal antibodies used in the study is shown in table 3. Their pattern of reactivity to cells in normal tissues has been characterised. ${ }^{24-30} \mathrm{RFD1}^{+}$ and $\mathrm{RFD7}^{+}$appear to identify distinct macrophage subsets in normal tissues.

\section{IMMUNOPEROXIDASE STAINING}

A standard prototol for the indirect immunoperoxidase method was used. ${ }^{31}$ The cytospin preparations were first incubated with each monoclonal antibody and phosphate buffered saline (PBS), at an optimal dilution, for one hour. After washing in PBS, the cytospin preparations were incubated for 45 minutes 
Table 3 Panel of monoclonal antibodies

\begin{tabular}{|c|c|c|c|c|c|}
\hline Designation & $(C D)$ & $\begin{array}{l}\text { Mol wt } \\
(k d)\end{array}$ & $\begin{array}{l}\text { Ig } \\
\text { class }\end{array}$ & Source & Reactivity in normal tissues \\
\hline $\begin{array}{l}\text { RFD1* } \\
\text { RFD7† } \\
\text { RFD9 } \\
\text { RFDR } \\
\text { UCHM1 } \\
\text { RFT2 } \\
\text { Leu3a } \\
\text { RFT8 } \\
\text { RFTmix } \\
\text { Anti-Tac }\end{array}$ & $\begin{array}{l}- \\
- \\
\overline{-} \\
(\text { CD14) } \\
\text { (CD7) } \\
\text { (CD4) } \\
\text { (CD8) } \\
\text { (CD2, 3, 7, 8) } \\
\text { (CD25) }\end{array}$ & $\begin{array}{l}28-33 \\
77 \\
28-33 \\
15 \\
40 \\
60 \\
32,30 \\
\frac{53}{3}\end{array}$ & 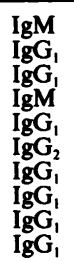 & $\begin{array}{l}\text { RFHSM } \\
\text { RFHSM } \\
\text { RFHSM } \\
\text { RFHSM } \\
\text { Dr Beverley } \\
\text { RFHSM } \\
\text { Becton Dickinson } \\
\text { RFHSM } \\
\text { RFHSM } \\
\text { Dr Uchiyama Kyoto }\end{array}$ & $\begin{array}{l}\text { Interdigitating cells, small proportion of B cells }{ }^{24} \\
\text { Mature tissue macrophages } \\
\text { Epithelioid cells, }{ }^{26} \text { tingible body macrophages } \\
\text { Class II MHC antigen, framework epitope }{ }^{26} \\
\text { Circulating monocytes } \\
\text { "Blast" forms of T cells }{ }^{28} \\
\text { Helper-inducer cells } \\
\text { Suppressor-cytotoxic T cells" } \\
\text { All T lymphocytes }{ }^{28} 29 \\
\text { IL-2 receptors on activated T lymphocytes }{ }^{30}\end{array}$ \\
\hline
\end{tabular}

Ig-immunoglobulin; RFHSM-Royal Free Hospital School of Medicine; UCH-University College Hospital, London; MHC-major $\times$ histocompatibility complex; IL-2-interleukin 2.

*Precipitated a 28-33 KD molecule from appropriate cell lines but its expression is restricted in immunohistological preparations to the cells stated above. Langerhans cells, for example, do not show it. It would appear therefore to be an epitope on a class II MHC molecule, which is . only "visible" in a very restricted population of cells or when specific function is expressed.

†Only reacts with tissue macrophages in normal tissues. It does not react with circulating monocytes or the tingible body macrophages in germinal centres.

$₫$ Reacts with epithelioid cells in granulomas and tingible body macrophages in germinal centres. It is also weakly expressed by some $\stackrel{\circ}{\supset}$ endothelial cells.

with peroxidase conjugated rabbit anti-mouse immunoglobulin (DAKO Immunoglobulin a/s, Copenhagen). After further washing in PBS the preparations were developed for 5-15 minutes in freshly made diaminobenzidine and hydrogen peroxide solution. The cytospins were counterstained in haematoxylin for $20-40$ seconds, dehydrated, mounted with coverslips in DPX, and examined under a light, oil immersion microscope. Three hundred cells were counted in successive high power fields and assessed as being either positive or negative (background staining only) for each antibody; the results were expressed as the percentage of cells that were positive. Positive controls (tonsil sections) were used with each antibody in all staining sessions. Negative controls (PBS incubation instead of first layer monoclonal antibody) were used for each patient, to assess background staining.

\section{DOUBLE IMMUNOFLUORESCENCE}

A standard technique for the simultaneous identification of two cellular antigens was used. ${ }^{32}$ Fifty microlitres of each relevant monoclonal antibody were mixed and incubated with the cytospin preparations for one to two hours. After being washed in PBS, they had a $50 \mu \mathrm{l}$ mixture of goat anti-mouse immunoglobulin $M$ tetraethyl rhodamine isothiocyanate (TRITC) and goat anti-mouse immunoglobulin G fluorescein isothiocyanate (FITC) (both from Southern Biotechnology Associates) added as a second layer; this was incubated for 45 minutes. After the PBS washing, the cytospin slides were mounted with coverslips in PBS and glycerol and examined immediately with a fluorescence microscope. Two hundred cells were counted in successive high power fields, first under phase contrast and then with appropriate barrier filters for TRITC and FITC. The cells fluoresc- ing either red only, green only, or both were counted and the number was expressed as a percentage of the total cells. Again positive and negative controls were always performed.

\section{ANALYSIS}

Statistical analysis was performed with Student's $t$ test or, when the results were not normally distributed, the Mann-Whitney U test.

\section{Results}

DIFFERENTIAL CELL COUNTS IN LAVAGE FLUID The differential cell counts in lavage fluid in the normal control subjects and patients with sarcoidosis are shown in figure 1 . Total cell counts were higher in the patients with sarcoidosis than in the control subjects $(p<0.005)$. The mean (SEM) percentage of lymphocytes was higher (34 (3)) and the proportion of 0 macrophages lower (61 (4)) than the values in the normal subjects (7(3) and 91 (3) respectively). The 9 total numbers of both macrophage like cells and $\frac{D}{O}$ lymphocytes were higher in the patients with sarcoid $(\mathrm{p}<0.01)$.

\section{IMMUNOCYTOLOGICAL ANALYSIS}

Macrophage like cells

Virtually all the lavage cells with macrophage morphology from both the normal subjects and the patients with sarcoidosis expressed RF-DR (mean $ळ$ $86 \%$ (SEM $2 \%$ ) and $92 \%(2 \%)$ respectively, fig $2 a$ ). The percentage of the cells that were $\mathrm{RFDI}^{+}$was ${ }^{\circ}$ significantly higher in the patients with sarcoidosis $(69 \stackrel{\vec{D}}{\mathrm{D}}$ (5)) than the normal subjects $(39(5), \mathrm{p}<0.001)$, whereas the percentage of RFD $7^{+}$cells did not differ $\stackrel{\mathbb{Q}}{\Omega}$ significantly between the two groups (normal 33 (4)); 

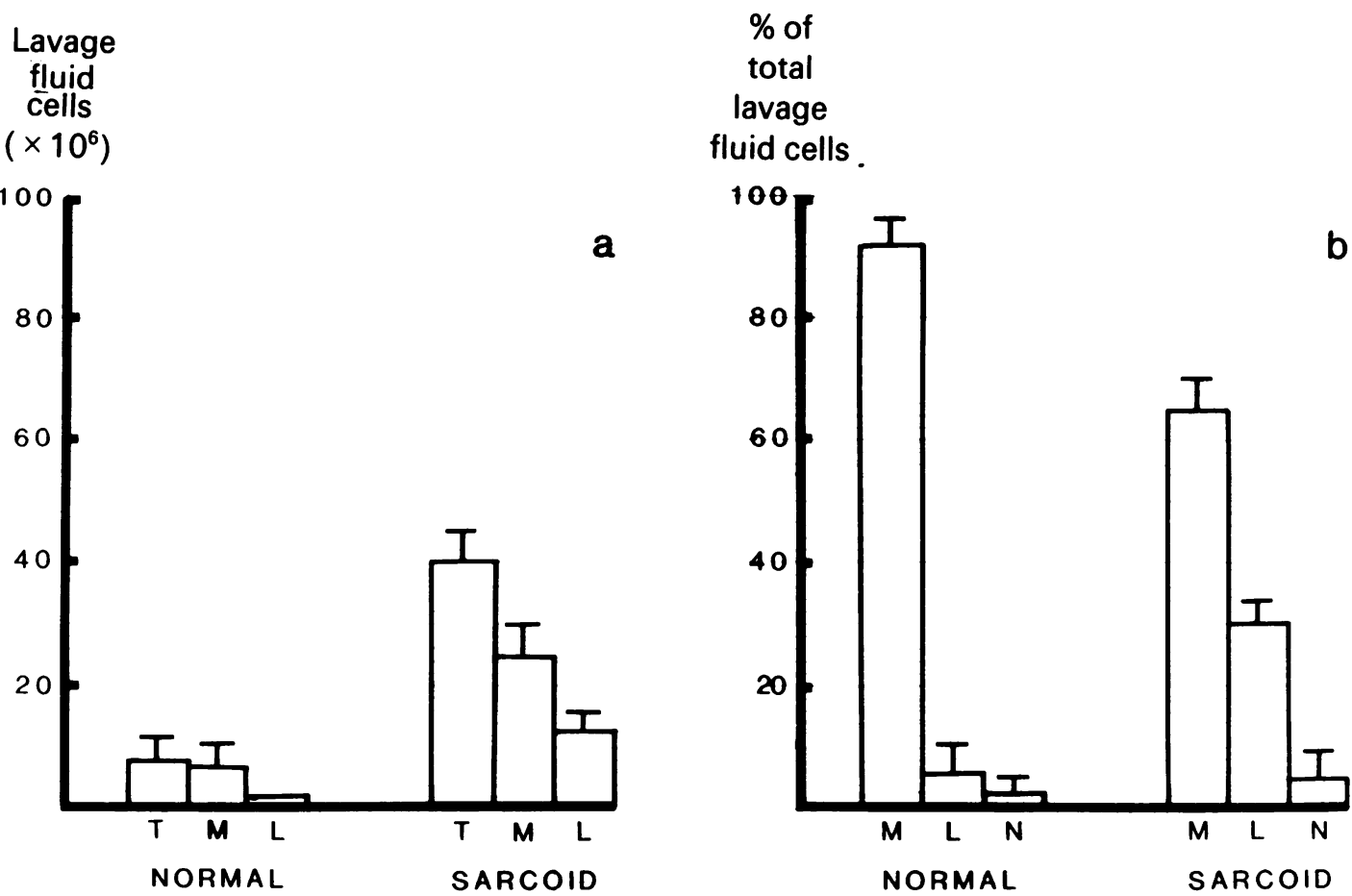

Fig 1 (a) Counts of total cells $(T)$, macrophages $(M)$, and lymphocytes $(L)$ recovered by bronchoalveolar lavage, and $(b)$ differential counts of macrophages $(M)$, lymphocytes $(L)$, and neutrophils $(N)$ in lavage fluid from normal subjects and subjects with sarcoidosis. Bars represent mean and standard error in each case.

sarcoid (45 (4); $p>0.05)$. Only a small percentage of macrophage like cells in lavage fluid from normal subjects expressed RFD1 and RFD7 (10 (2)) with double immunofluorescence, whereas a substantial percentage of cells $(36(3))$ in the samples from patients with sarcoid were RFD1 ${ }^{+}$and $\mathrm{RFD}^{+}(\mathrm{p}<0.0001)$. In lavage fluid from normal subjects only a small percentage of cells were RFD9 ${ }^{+}(9(1 \cdot 5))$ or $\mathrm{UCHMI}^{+}$ (7 (3)); in patients with sarcoidosis the percentages of both were higher (29 (4) and 28 (5) respectively; p < 0.01 ). There was no significant difference in the proportion of macrophages expressing any of these markers between smokers and non-smokers in either group. There was also no difference between the results from the control patients and the normal volunteers.

\section{LYMPHOCYTES}

No identifiable B cells were found in any sample (data not shown). Of the $\mathrm{T}$ cells, $\mathrm{CD}^{+}$cells ( $\mathrm{T} \mathrm{mix}^{+}, \mathrm{CD}^{-}$ cells, helper-inducer lymphocyte subset) outnumbered $\mathrm{CD}^{+}$(suppressor-cytotoxic lymphocyte subset) cells in all samples. The ratio CD4:CD8 was higher in lavage fluid from patients with sardoidosis (mean
4.8:1) than from normal subjects (1.9:1) (fig 2b), though a wide range of values was seen. The proportion of $T$ cells strongly expressing CD7 antigen (RFT2) and RF-DR was higher in patients with sarcoidosis than in control subjects though again a wide range of results was recorded (mean $21 \%(4 \%) v$ $7 \%(1 \%)$ for both; $\mathrm{p}<0.05$ : fig $2 b)$. There was a significant difference $(p<0.05)$ between lavage fluid from normal subjects and patients with sarcoidosis in terms of percentage of $\mathrm{Tac}^{+} \mathrm{T}$ cells $(9(2) \vee 2(0.4)$. Again, there was no difference in the percentages between smokers and non-smokers or between patient controls and normal volunteer controls.

RELATION BETWEEN IMMUNOCYTOLOGICAL RESULTS AND SPECIFIC INDICES OF CLINICAL DISEASE

There was no correlation between duration of disease, forced vital capacity, TLCO, or presence of a raised serum angiotensin converting enzyme concentration and the proportion of alveolar macrophages and lymphocytes expressing any of the markers studied (comparative data not shown). 

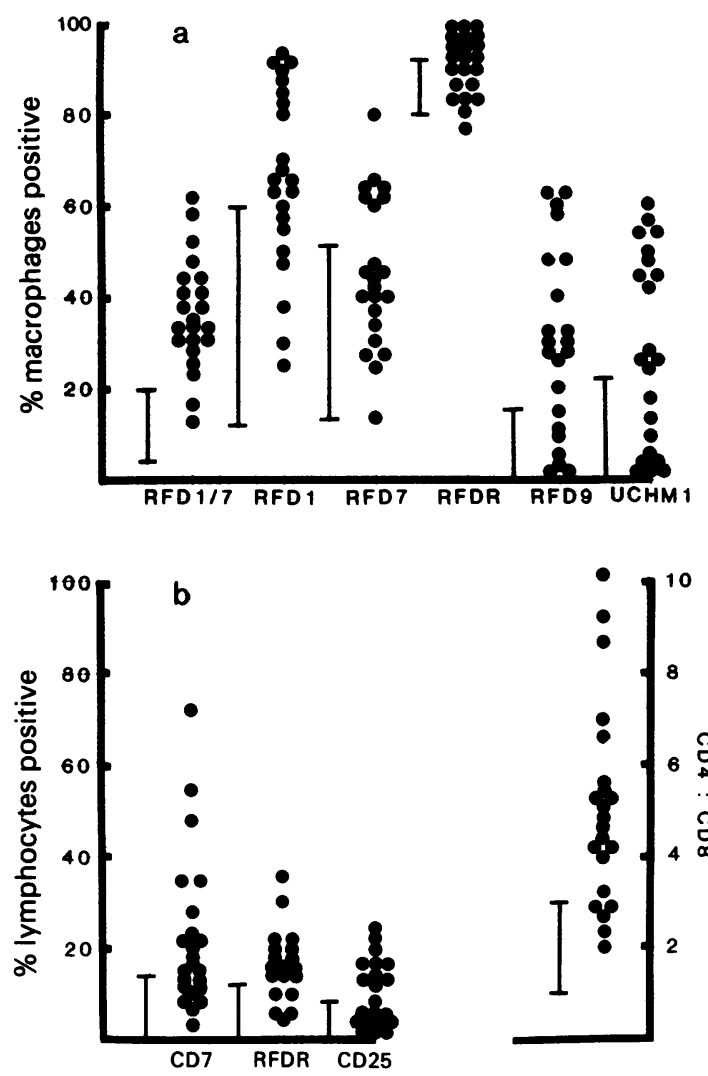

Fig 2 (a) Proportion of total non-lymphoid mononuclear cells in lavage fluid from patients with sarcoidosis identified by specific monoclonal antibodies to macrophage subsets by means of the immunoperoxidase and double immunofluorescence methods used on cytospin preparations. Bars represent the range of results obtained from normal volunteers. Subjects in column 1 (RFD1/7) are also included in columns 2 and 3 (where RFDI and RFD7 are expressed separately). (b) Proportion of total lymphoid cells in lavage fluid from patients with sarcoidosis expressing CD7 antigen, HLA-DR (RFDR), and CD25 antigen (anti-Tac). The relative proportions of $C D 4^{+}$and $C D 8^{+}$lymphocytes are given. Bars represent the range of results obtained from normal volunteers.

\section{RELATION BETWEEN IMMUNOCYTOLOGY AND} RADIOGRA PHIC STAGING OF SARCOIDOSIS

Patients with stage II and III chest radiographic shadowing had higher proportions of $\mathrm{RFD1}^{+}$and $\mathrm{RFD}^{+}$macrophage like cells than those with a stage I chest radiograph (for both $p<0.05$ : fig 3) and a larger number of cells expressing both RFD1 and RFD7 ( $p$ $<0.005$ ). No difference was found in $\mathrm{RFDR}^{+}$macrophage like cells, but the proportion of RFD9 ${ }^{+}$and UCHM ${ }^{+}$cells was increased $(p<0.05$ and $p<0.01$

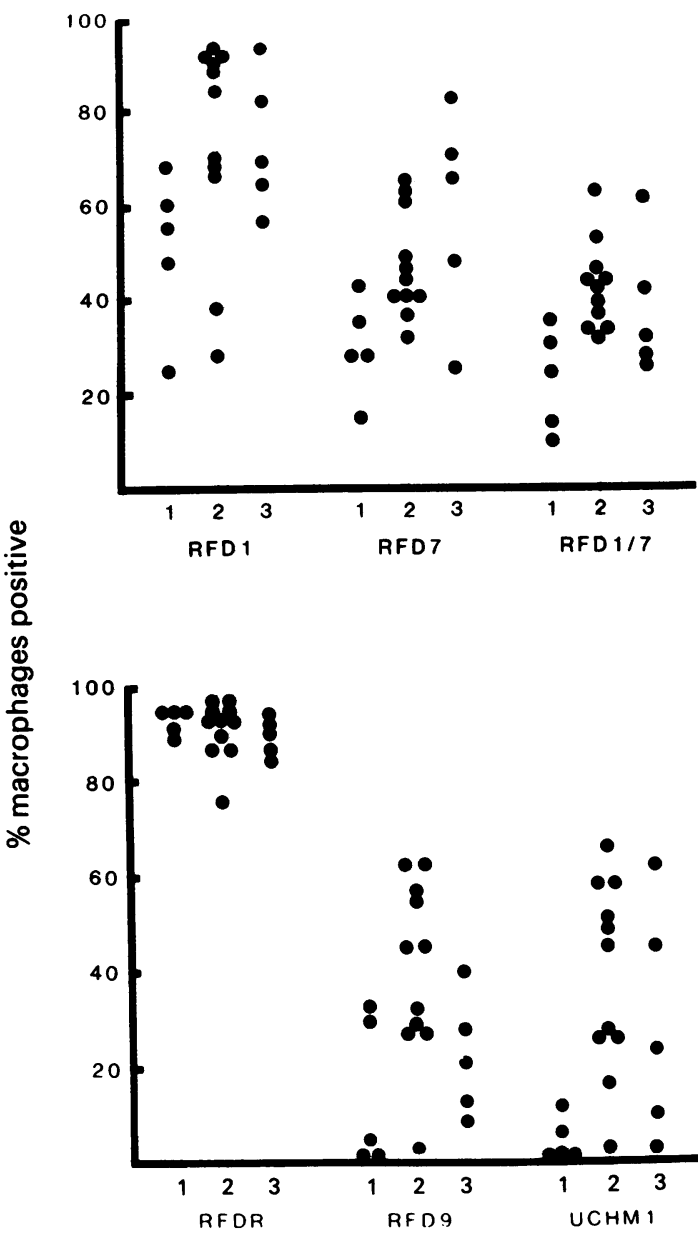

Fig 3 Relative proportions of lavage fluid non-lymphoid mononuclear cells expressing reactivity with monoclonal antibodies RFD1, RFD7, and both (RFD1/7) as well as RFDR, RFD9, and UCHMI, in patients with sarcoidosis according to radiographic stage $(I, I I, I I)$. Mean and standard error in each group is quoted in the text.

Immunoperoxidase methods were used on cytospin preparations in each case and double immunofluorescence for RFD1/7.

respectively: fig 3). When lymphocyte subsets were $N$ analysed no significant differences were found in $\mathrm{N}$ CD4:CD8 ratios or $\mathrm{RF}-\mathrm{DR}{ }^{+} \mathrm{T}$ cells. The lavage fluid $\omega$ of patients with a stage II or III chest radiograph had more RFT2 ${ }^{+}(\mathrm{CD} 7)$ and $\mathrm{Tac}^{+}(\mathrm{CD} 25) \mathrm{T}$ cells than the $\stackrel{\varrho}{=}$ lavage fluid from patients with a stage I pattern $(p<\Phi$ 0.05 and $<0.01$; data not shown).

\section{IMMUNOCYTOLOGICAL FINDINGS RELATED TO} DISEASE ACTIVITY

The proportion of $\mathrm{RFDR}^{+}$macrophage like cells and $\stackrel{\circ}{\circ}$ $\mathrm{RFDl}^{+}$cells in lavage fluid were similar in the patients 
$\%$

macrophages
positive

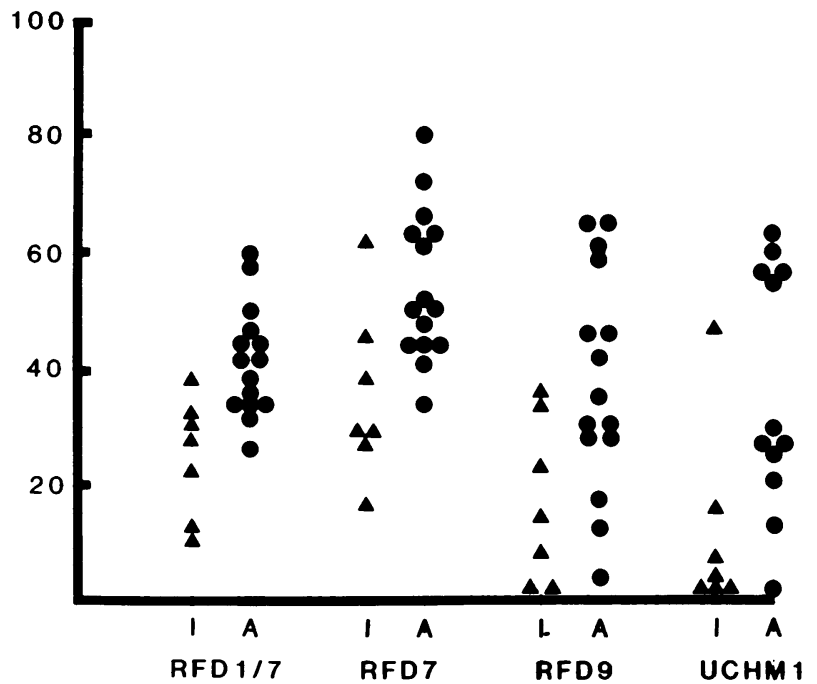

$\%$

lymphocytes

positive

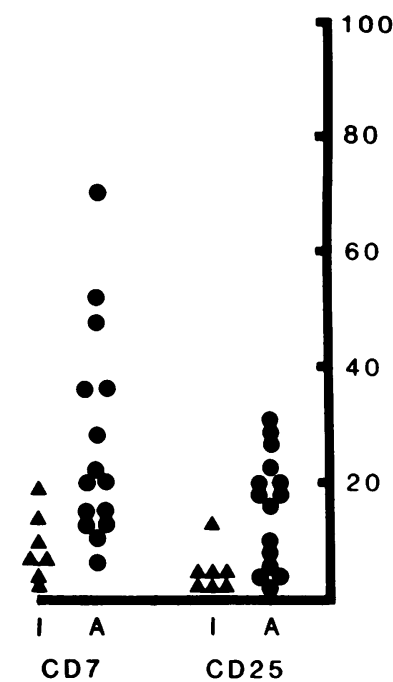

Fig 4 Proportions of lavage fluid subsets in groups of patients with inactive (I-triangles) and active ( $A$-circles) sarcoidosis identified by specific monoclonal antibodies (for reactivity see text). Mean and standard error in each case are quoted in the text. Immunoperoxidase and double immunofluorescence methods were used on cytospin preparations.

judged to have active and inactive sarcoidosis (data not shown). Patients with active disease had higher percentages of RFD7 ${ }^{+}$cells $(51(3 \cdot 1) v 32(7 \cdot 6) ; \mathrm{p}<$ 0.05), RFD9 ${ }^{+}$cells $(37$ (5.6) v $13(5) ; \mathrm{p}<0.05)$, $\mathrm{UCHM}^{+}$cells $(38(5 \cdot 2) v 9(6 \cdot 1) ; \mathrm{p}<0.005)$, and cells expressing both RFD1 and RFD7 antigens (41 (3.6) $v$ 23 (1.9); $<<0.005$ ) (fig 4) and higher percentages of $\mathrm{CD}^{+}$and $\mathrm{CD} 25^{+}$lymphocytes $(\mathrm{p}<0.05$ and $<0.01$; fig 4).

\section{Discussion}

We have shown significant variations in the proportions of phenotypically distinct subsets of alveolar macrophages and lymphocytes between patients with sarcoidosis and normal subjects; the increase in the proportions of certain phenotypically distinct cells correlated with disease activity as determined by clinical criteria.

A very high proportion of lavage macrophages from patients with sarcoidosis coexpressed antigens recognised by the monoclonal antibodies RFD1 and RFD7. RFD1 recognises a cell membrane antigen related to HLA-DR, ${ }^{24}$ though not all HLA-DR cells coexpress RFD1 (for example, Langerhans cells ${ }^{33}$ ). This suggests that RFD1 recognises an epitope with restricted expression. Chronic inflammatory diseases such as cryptogenic fibrosing alveolitis, rheumatoid arthritis, and eczema are characterised by the presence of increased proportions of RFD1 ${ }^{+}$cells. $^{3435}$ The functional role of the RFD1 epitope in antigen presentation has been confirmed by studies where addition of the RFD1 monoclonal antibody inhibited the mixed lymphocyte reaction. ${ }^{36}$

RFD7 antibody recognises a cytoplasmic antigen (77 kd) of mature tissue macrophages, which are usually also positive for acid phosphatase and which are efficiently phagocytic. The RFD7 antibody does not stain dendritic cells. ${ }^{24}$ Previous studies have shown that RFD1 and RFD7 antigens are separate in the developing fetus ${ }^{26}$ and are mutually exclusive in normal secondary lymphoid tissue, skin, and cultured peripheral blood monocytes. ${ }^{22}$ Coexpression of D1 and D7 has been previously found in diseases associated with chronic inflammation. ${ }^{3}$ We have now shown that a very small proportion of bronchoalveolar macrophages from normal subjects express both antigens; in patients with sarcoidosis this double expression is significantly increased. This result might indicate that such cells are immature and have not yet developed along separate pathways to express eventually one or the other antigen as mature cells. A second possibility is that dual antigen expression is the product of the local immune environment-that is, induced by lymphocyte interaction or soluble mediators. Classic RFD7 ${ }^{+}$macrophages could, for example, be influenced by their environment to become RFD ${ }^{+}$. Langerhans cells have been shown to 
become RFD1 ${ }^{+}$when included in the lesions of atopic eczema. ${ }^{35}$ Whether this also results in functional change is not known. Certainly double expression of RFD1/D7 is substantially increased in sarcoidosis, and was associated with increasing disease activity and radiographic evidence of more extensive lung lesions. In most patients with sarcoidosis, especially those with active disease, the proportions of macrophages expressing RFD1, D7, and UCHM1 add up to more than $100 \%$. Much of this "surfeit" of cells is explained by the double expression of RFD1 and RFD7. There is also, however, double (or more than double) expression of other macrophage markers. In most normal subjects the proportions add up to less than $100 \%$, so that some of the macrophages must express none of these antigens. Furthermore, identification of these antigens depends on the expression of a sufficient concentration. The possibility remains that "negative" cells simply express small amounts of antigen below the detection threshhold of the techniques used.

Increased numbers of activated $\mathrm{T}$ lymphocytes are also recovered in lavage fluid from patients with sarcoidosis, as evidenced by significantly higher proportions of strongly RFT2 ${ }^{+}$(CD7 cluster) lymphocytes than in lavage fluid from normal subjects. Some of these cells also express other activation markers - that is, interleukin-2 receptors (identified by the anti-Tac antibody against the CD25 antigen) and class II MHC (identified by the RFDR monoclonal antibody). Expression of all these antigens was increased on the alveolar lymphocytes from patients with sarcoidosis, especially those with active disease and stage II and III chest radiographs. Increased proportions of activated lymphocytes have been reported previously. ${ }^{121}$ Levels of lymphocytosis in lavage fluid have been suggested as being a good marker of disease activity, ${ }^{15}{ }^{17}$ though other workers have cast doubt on this idea. ${ }^{19}$ The present study also fails to show correlations between lymphocytosis or lymphocyte activation and disease activity. Interestingly, relatively reduced levels of strong CD7 expression and HLA-DR expression occur in lavage fluid from patients with stage III disease. As this occurs at a time when the RFD1 ${ }^{+} / \mathrm{RFD}^{+}$macrophages form a major population in the lavage fluid, the possibility is suggested that this population in some way suppresses lymphocyte function. Such a possibility must, however, be tested by functional studies using isolated cells in vitro.

We have thus found higher proportion of alveolar macrophages expressing RFD1, RFD9, and UCHM1 and coexpressing RFD1/D7, and of alveolar lymphocytes expressing CD7 antigen and HLA-DR and interleukin-2 receptors in patients with sarcoidosis than in normal subjects. In patients with active disease and widespread lung lesions the increased proportions of $\mathrm{RFD}^{+}, \mathrm{RFD}^{+}, \mathrm{UCHMI}^{+}$, and $\mathrm{RFD} 1^{+} / \mathrm{RFD}^{+}$ lavage fluid macrophages and of RFT2 ${ }^{+}$(CD7) and $\stackrel{\times}{.}$ $\mathrm{Tac}^{+}$(CD25) lavage fluid lymphocytes are particularly $\overrightarrow{\vec{F}}$ striking. None of the monoclonal antibody markers showed any correlation with disease duration, results $\frac{C}{0}$ of pulmonary function tests, or increased serum $\overline{\frac{5}{5}}$ angiotensin converting enzyme activity when separate comparisons were made. Although these data suggest that lavage immunocytology may provide clues to ${ }^{\infty}$ underlying immune pathogenetic mechanisms, and $\vec{O}$ may be of value in assessing disease activity, results as yet do not prove or confirm that the assessment of surface phenotype can be used in determining prog- $\vec{F}$ nosis or making therapeutic decisions for individual $x$ patients. Such conclusions await the results of con- + trolled, prospective investigations of patients with thisis disease.

This work was supported in part by a grant from? Draco Pharmaceutical, Lund, Sweden, and GMA was. supported by an ICI postgraduate clinical research scholarship.

\section{References}

1 Hunninghake GW, Crystal RG. Pulmonary sarcoidosis a disorder mediated by excess helper T-lymphocyteo activity at sites of disease activity. $N$ Engl J Me 1981;305:429-34.

2 Venet A, Hance AJ, Saltini C, Robinson BWS, Crysta RG. Enhanced alveolar macrophage-mediateof antigen-induced T-lymphocyte proliferation in sar coidosis. J Clin Invest 1985;75:293-301.

3 Campbell DA, Poulter LW, du Bois RM. Phenotypie. analysis of alveolar macrophages in normal subjects and in patients with interstitial lung disease. Thorase 1986;41:429-34.

4 Hance AJ, Douches S, Winchester RJ, Ferrans VJơ Crystal RG. Characterization of mononuclea? phagocyte subpopulations in the human lung by using monoclonal antibodies: changes in alveolar macroß phage phenotype associated with pulmonary $\mathbf{s a r}^{\circ}$ coidosis. J Immunol 1985;134:284-92.

5 Biondi A, Rossing TH, Bennett J, Todd RF. Surface membrane heterogeneity among human mononuclea phagocytes. J Immunol 1984;132:1237-43.

6 Lawrence EC, Teague RB, Gottlieb MS, Jinghran SG, Lieberman J. Serial changes in markers of diseas activity with corticosteroid treatment in sarcoidosis Am J Med 1983;74:747-56.

7 Baughman RP, Fernandez M, Bosken $\mathrm{CH}$, Mantil Hurtubis P. Comparison of Gallium-67 scanning大 bronchoalveolar lavage, and serum angiotensin con verting enzyme levels in pulmonary sarcoidosis. $\mathrm{Am}^{+}$ Rev Respir Dis 1984;129:676-81.

8 Line BR, Hunninghake GW, Keogh BA, Jones $A E_{+}^{O}$ Johnston GS, Crystal RG. Gallium-67 scanning to stage alveolitis of sarcoidosis: correlation with clinicap studies, pulmonary function studies, and bronchoalveolar lavage. Am Rev Resp Dis 1981;123:440-6\%

9 Abe S, Munakata M, Nishimura M, et al. Gallium-68 scintigraphy, bronchoalveolar lavage, and pat 
ological changes in patients with pulmonary sarcoidosis. Chest 1985;85:650-5.

10 Hollinger WM, Staton GW, Fajman WA, Gilman MJ, Pine JR, Check IJ. Prediction of therapeutic response in steroid-treated pulmonary sarcoidosis. Evaluation of clinical parameters, bronchoalveolar lavage, gallium-67 scanning, and serum angiotensin converting enzyme levels. Am Rev Respir Dis 1985;132:65-9.

11 Cueppens JL, Lacquet LM, Marien G, Demedts M, Van Den Eeckhout A, Stevens E. Alveolar T-cell subsets in pulmonary sarcoidosis: Correlation with disease activity and effect of steroid treatment. Am Rev Respir Dis 1984;129:563-8.

12 Klech H, Kohn H, Kummer F, Mostbeck A. Assessment of activity in sarcoidosis: sensitivity and specificity of 67-gallium scintigraphy, serum angiotensin converting enzyme levels, chest roentgenography, and blood lymphocyte subpopulations. Chest 1982;82:732-8.

13 Lieberman J, Schleissner LA, Nosal A, Sastra A, Mishkin FS. Clinical correlations of serum angiotensin converting enzyme (ACE) in sarcoidosis. Chest 1983;84: 522-8.

14 Ainslie GM, Benatar SR. Serum angiotensin converting enzyme in sarcoidosis: sensitivity and specificity in diagnosis: correlations with disease activity, duration, extra-thoracic involvement, radiographic type and therapy. $Q J$ Med 1985;55:253-70.

15 Keogh BA, Hunninghake GW, Line BR, Crystal RG. The alveolitis of pulmonary sarcoidosis-evaluation of natural history and alveolitis-dependent changes in lung function. Am Rev Resp Dis 1983;128:256.

16 Israel-Biet D, Venet A, Chretien J. Persistent high alveolar lymphocytosis as a predictive criterion of chronic pulmonary sarcoidosis. In: Johns CJ, ed. Tenth international conference of sarcoidosis and other granulomatous disorders. Ann NY Acad Sci 1986;465:672-7.

17 Bell DY, Johnson SM, Piantadosi CA. Elevated serum immunoglobulin $\mathrm{G}$ levels and bronchoalveolar lymphocytosis as predictors of clinical course in pulmonary sarcoidosis. In: Johns CJ, ed. Tenth international conference of sarcoidosis and other granulomatous disorders. Ann NY Acad Sci 1986;465:672-7.

18 Buchalter S, App W, Jackson L, Chandler D, Jackson R, Fulmer J. Bronchoalveolar lavage cell analysis in sarcoidosis: a comparison of lymphocyte counts and clinical course. In: Johns CJ, ed. Tenth international conference of sarcoidosis and other granulomatous disorders. Ann NY Acad Sci 1986;465:678-84.

19 Turner-Warwick M, McAllister W, Lawrence R, Britten A, Haslam PL. Corticosteroid treatment in pulmonary sarcoidosis: do serial lavage lymphocyte counts, serum angiotensin converting enzyme measurements, and gallium-67 scans help management? Thorax 1986;41:903-13.

20 Reynolds HY. Bronchoalveolar lavage: state of the art. Am Rev Respir Dis 1987;135:259-63.

21 International Labor Office. Guidelines for the Use of the ILO International Classification of Radiography of Pneumoconiosis. Geneva: ILO, 1980. (Occupational Safety and Health Series, No 80.)

22 DeRemee RA, Rohrbach MS, SACE activity in evaluating the clinical course in sarcoidosis. Ann Intern Med 1980;92:361-5.
23 Rohatgi PK, Ryan JW, Lindeman P. Value of serial measurement of SACE in the management of sarcoidosis. Am J Med 1981;70:44-50.

24 Poulter LW, Campbell DA, Munro C, Janossy G. Discrimination of human macrophages and dendritic cells by means of monoclonal antibodies. Scand $J$ Immunol 1986;24:351-7.

25 Munro CS, Campbell DA, Collings LA, Poulter LW. Monoclonal antibodies distinguish between macrophages and epithelioid cells in sarcoidosis and leprosy. Clin Exp Immunol 1987;68:269.

26 Janossy G, Bofill M, Poulter LW, Rawlings E, Burford GD, Navarrete C, Ziegler A, Keleman E. Separate ontogeny of two macrophage-like accessory cell populations in the human fetus. J Immunol 1986; 136:4354-61.

27 Hogg N, MacDonald S, Slugarando D, Beverley PCL. Monoclonal antibodies specific for human monocytes, granulocytes and endothelium. Immunology 1984;53: 753-9.

28 Batory G, Bofill M, Petranyi GS, Janossy G, Hollan SR. Comparative analysis of monoclonal antibodies of workshop $\mathrm{T}$ series on suspensions and tissue sections. In: Bernard A, Boumsell L, Dausset J, Milstein C, Schlossman SF, eds. Leucocyte typing. First international workshop on human leucocyte differentiation antigens. Berlin: Springer-Verlag, 1984:469-75.

29 Janossy G, Prentice HG. T cell subpopulations, monoclonal antibodies and their therapeutic applications. Clin Haematol 1982;11:631-60.

30 Uchiyama T, Broder S, Waldmann TA. A monoclonal antibody (anti-Tac) reactive with activated and functionally mature human T cells. I. Production of antiTac monoclonal aitibody and distribution of tacpositive cells. J Immunol 1981;126:1393-7.

31 Mason DY, Abdulaziz Z, Falini B, Stein H. Double immunoenzymatic labelling. In: Polak J, Van Noorden S, eds. Immunocytochemistry: practical applications in pathology and biology. Bristol: Wright, 1983:113-28.

32 Poulter LW, Chilosi M, Seymour GJ, Hobbs S, Janossy G. Immunofluorescence membrane staining and cytochemistry, applied in combination for analysing cell interactions in situ. In: Polak J, Van Noorden S, eds. Immunocytochemistry: practical applications in pathology and biology. Bristol: Wright, 1983:233-48.

33 Poulter LW, Collings LA, Tung KS, Waters MJ. Parasitism of antigen presenting cells in hyperbacillary leprosy. Clin Exp Immunol 1984;55:611-7.

34 Poulter LW, Duke O, Hobbs S, Janossy G, Panayi G, Seymour G. The involvement of interdigitating (antigen presenting) cells in the pathogenesis of rheumatoid arthritis. Clin Exp Immunol 1983;51: 247-54.

35 Alegre VA, MacDonald DM, Poulter LW. The simultaneous presence of Langerhans cell and interdigitating cell antigenic markers on inflammatory dendritic cells. Clin Exp Immunol 1986;64:330-3.

36 Poulter LW, Duke O. Dendritic cells of the rheumatoid synovial membrane and synovial fluid. In: Clot J, Sang $\mathrm{J}$, eds. Proceedings of quatrième cours d'immunorheumatologie et séminaire international d'immunopathologie articulaire. Montpellier: 1983:189-99. 